\title{
Lateral torsional buckling of doubly symmetric I-shaped steel members under linear moment gradient
}

\author{
Çift simetri eksenli I-enkesitli çelik elemanların doğrusal değişen \\ momentler altındaki yanal burulmalı burkulma davranıșı
}

\author{
Ertuğrul Türker UZUN*, Mutlu SEÇER ${ }^{2}$
}

1Department of Civil Engineering, Faculty of Engineering, Izmir Institute of Technology, Izmir, Turkey. ertugruluzun@iyte.edu.tr

${ }^{2}$ Department of Civil Engineering, Faculty of Engineering and Architecture, Izmir Katip Celebi University, Izmir, Turkey. mutlu.secer@ikc.edu.tr

Received/Geliş Tarihi: 19.03.2018, Accepted/Kabul Tarihi: 07.09.2018

* Corresponding author/Yazışılan Yazar

doi: $10.5505 /$ pajes.2018.46656

Research Article/Araștırma Makalesi

\section{Abstract}

Due to technical developments and wider range of applications in the steel structures, significance of the research on structural stability problems become forward. Lateral torsional buckling is a major problem especially for doubly symmetric I-shaped steel members subjected to flexure about their strong axis. If these members are not appropriately braced against lateral deflection and twisting, they are under the risk of failure by lateral torsional buckling prior to the reach their load carrying capacity. In this study, elastic lateral torsional buckling behavior of doubly symmetric I-shaped steel members under linear moment gradient is investigated considering a proposed method several design standards and codes, approaches from the literature and finite element analysis. Proposed method herein is based on finite difference solution of lateral torsional buckling differential equation considering linear moment gradient. Different unbraced member lengths and various end moment values are considered in order to compare and evaluate these approaches in terms of critical moment and moment modification factor. Analysis results show that lateral torsional buckling is a key issue for doubly symmetric I-shaped steel members that are under flexure and it is reflected satisfactorily with the proposed method considering the design codes and standards, approaches from the literature and finite element analysis results.

Keywords: Lateral torsional buckling, Doubly symmetric I-shaped steel member, Structural steel design, Moment modification factor

\section{Introduction}

In the design practice of steel members under flexure, local buckling potential and the post buckling resistance, the yield and/or rupture strength of cross-section have been significant parameters for structural engineers. Lateral torsional buckling, where the deformation changes from predominantly in-plane bending to combined lateral deflection and twisting, is one of the most important stability problems and should be controlled in the design phase of steel structural members. If adequate precautions have not been taken, the final failure pattern involves lateral deflection and twisting in combination with various extents of yielding and flange and/or web local buckling depending on the specific member characteristics [1]. Despite the fact that lateral torsional buckling is a key issue in structural steel design, the analytical aspects of determining lateral torsional buckling strength have been complex and closed form solutions exist only for few cases. Therefore,
Öz

Celik yapılardaki teknik gelișmeler ve daha geniș uygulama alanları nedeniyle yapısal stabilite problemleri üzerine yapılan araștırmaların önemi artmaktadır. Yanal burulmalı burkulma, özellikle kuvvetli eksenlerinde eğilmeye maruz kalmış çift simetri eksenli I-kesitli çelik elemanlar için önemli bir sorundur. Bu elemanlar yatay yer değiștirme ve dönmeye karșı uygun bir șekilde desteklenmezlerse, yük tașıma kapasitelerine ulaşamadan önce yanal burulmal burkulma riski altındadırlar. Bu çalısmada, farklı uç moment etkisi altındaki çift simetri eksenli I-kesitli çelik elamanların elastik yanal burulmal burkulma davranısı, önerilen bir yöntem ile birlikte çeșitli tasarım standartları, literatürdeki yaklaşımlar ve sonlu eleman analizleri dikkate alınarak incelenmiștir. Burada önerilen yöntem, doğrusal değisen moment etkisi altında yanal burulmalı burkulma davranıșını temsil eden diferansiyel denklemin sonlu farklar yöntemi ile çözümüne dayanır. Kritik moment ve moment düzeltme faktörü açısından bu yaklaşımları karşılaştırmak ve değerlendirebilmek için farklı yatay yönde tutulma uzunlukları ve cesitli uc moment değerleri dikkate alınmıştır. Analiz sonuçları, yanal burulmalı burkulmanın, eğilme altında bulunan çift simetri eksenli I-kesitli çelik elemanlar için önemli bir konu olduğu ve önerilen yöntem ile tasarım standartları, literatürdeki yaklașımlar ve sonlu elemanlar sonuçları ile karșılaştırıldığında sonuçların tatmin edici bir șekilde yansıtıldığını göstermektedir.

Anahtar kelimeler: Yanal burulmalı burkulma, Cift simetri eksenli Ikesitli çelik eleman, Celik yapı tasarımı, Moment düzeltme katsayısı

several design standards and codes have offered equations and approximations in order to calculate lateral torsional buckling behavior of steel members [2]. Because of its important effect on the design of steel structures, researchers maintain to investigate lateral torsional buckling from different aspects [3],[4]. Effects of lateral restraints on torsional and flexural bucking of members were examined for elastic and inelastic ranges [5],[6]. Additionally, geometric imperfection effects [7] and curved members [8] were discussed and influences on the member behavior are focused. Also, approaches using finite elements [9] and experimental studies [10],[11] were performed to evaluate lateral torsional buckling behavior. On the other hand, design standards and codes provided buckling solutions derived for uniform moment loading condition and account for variable moment along the unbraced length with moment modification factor, $\mathrm{Cb}$ applied to these. Consequently, moment modification factor have gained importance and studies have been performed to determine the moment capacity with adequate accuracy [12],[13]. One of the most 
extensive early work for determining lateral torsional buckling moment capacity was performed by Salvadory [14] and their results have been verified many times by other researchers [3]-[15] using numerical techniques. Kirby and Nethercot [16] presented an alternative equation for moment modification factor that can be applied to more general shapes of nonlinear moment diagrams. Besides, Serna et al. offered moment modification factor using finite element techniques [17]. Wong and Driver [18] proposed an equation for moment modification factor using improved quarter-point formula and their results were adequate for the majority of the cases they had considered. Lateral torsional buckling behavior and moment modification factors were also presented in stability books regarding their chronological order [19],[20].

In this study, lateral torsional buckling of I-shaped steel members under linear moment gradient were investigated and a function was proposed based on finite difference approach to be used in lateral torsional buckling calculations. Several design standard and code approaches, methods from the literature and finite element program outcomes were used for evaluating the proposed moment gradient function outcomes. Since different design standards vary substantially from one to another in the ways that they characterize the lateral torsional buckling behavior, this study also aimed to compare and evaluated these approaches using different unbraced member lengths and various end moment values. Lateral torsional buckling behaviors of steel members were examined in terms of critical moment and moment modification factor using graphics.

\section{Lateral torsional buckling of steel members}

Lateral torsional buckling is one of the major stability problems for members under flexure and it influences structural steel design directly. Lateral torsional buckling may occur suddenly and the movement is perpendicular to the direction of the applied load. For lateral torsional buckling type of failure, the critical moment, which is a function of lateral and torsional stiffness, under the applied load or moment should be reached. Critical moment is affected by the material properties, boundary conditions, unbraced length, load pattern, and dimensions of the member's cross section. However, the principal variable affecting lateral torsional buckling strength is the length of the unbraced segment of the member. Therefore, the distance between lateral and torsional braces has to be controlled precisely. Otherwise, beam may perform the influence of lateral torsional buckling, it experiences simultaneous in-plane displacement, lateral displacement and twisting because of bending.

In this study, a function is proposed based on finite difference approach in order to calculate moment capacity of the steel members under the effect of lateral torsional buckling. Outcomes of this proposed function are evaluated considering globally accepted standards and codes such as; EN 1993-1-1 [21], BS 5950 [22], AS 4100 [23], AISC 360-16 [24], TSDC-2016 [25] and TS 4561 [26]. Moreover, finite element based software and modification factors given in the literature [14],[16],[18] are also presented for precisely evaluating the efficiency of the proposed function.

In Figure 1 [27], I shaped steel member is subjected to uniform moment $M_{0}$ with respect to its major bending axis and it is simply supported from its ends. For this case, differential equation for considering lateral torsional buckling is given in Eqn. 1 [28].

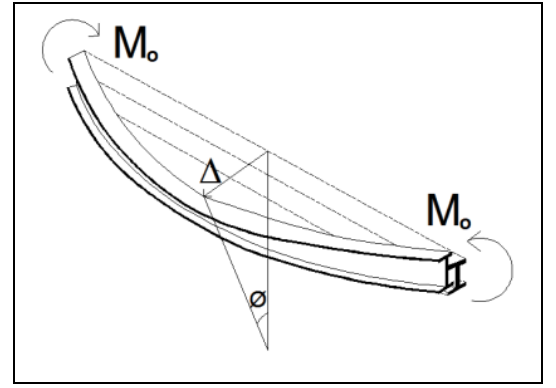

Figure 1: Lateral torsional buckling of doubly symmetric I shaped member under uniform moment $M_{0}$ [27].

$$
E C_{w} \frac{d^{4} \emptyset}{d z^{4}}-G J \frac{d^{2} \emptyset}{d z^{2}}-\frac{M_{0}^{2}}{E I_{y}} \emptyset=0
$$

Where: $E$ is the modulus of elasticity, $G$ is the shear modulus, $J$ is the torsional constant, $C_{w}$ is the warping constant, $I_{y}$ is the moment of inertia with respect to the weak axis, and $\varnothing$ is the twisting angle.

Nominal flexural strength according to the limit state of elastic lateral torsional buckling for a uniform bending moment diagram along the unbraced length $L=L_{b}$ can be written as Eqn. 2 if boundary conditions are assumed for both ends of the beam are not twisted but warped [28].

$$
M_{0 c r}=\frac{\pi}{L} \sqrt{E I_{y} G J+\left(\frac{\pi E^{2}}{L}\right)^{2} I_{y} C_{w}}
$$

\subsection{Lateral torsional buckling analysis using finite difference approach}

Differential equation of lateral torsional buckling is a fourth order differential equation and finite difference approach is considered for the solution. In this approach, first term of Taylor series of each derivative is used. In order to obtain numerical solution of $\varnothing$, member is divided into equally spaced grid points. At a point $z=z_{i}$, the first, second, third, and fourth derivatives of $\varnothing(z)$ can be written as Eqn. 3 - Eqn. 6 .

$$
\begin{gathered}
\emptyset_{i}^{\prime}=\frac{1}{2 \Delta z}\left(-\emptyset_{i-1}+\emptyset_{i+1}\right) \\
\emptyset_{i}^{\prime \prime}=\frac{1}{\Delta z^{2}}\left(\emptyset_{i-1}-2 \emptyset_{i}+\emptyset_{i+1}\right) \\
\emptyset_{i}^{\prime \prime \prime}=\frac{1}{2 \Delta z^{3}}\left(-\emptyset_{i-2}+3 \emptyset_{i-1}-3 \emptyset_{i+1}+\emptyset_{i+2}\right) \\
\emptyset_{i}^{\prime \prime \prime \prime}=\frac{1}{\Delta z^{4}}\left(\emptyset_{i-2}-4 \emptyset_{i-1}+6 \emptyset_{i}-4 \emptyset_{i+1}+\emptyset_{i+2}\right)
\end{gathered}
$$

Finite difference representation at a grid point for fourth order differential equation contains five function values. Therefore, the use of Eqn. 3-Eqn. 6 at a beam end, which is shown as grid point $\mathrm{O}$ in Figure 2, requires two extra function values, namely $\emptyset_{-1}$ and $\emptyset_{-2}$. Two equations at point 0 are required in order to represent boundary conditions at that point.

If a beam is divided into $m$ segments, then the use of finite difference methods requires four additional function values. There are $(m+1)$ finite difference equations for $(m+5)$ unknowns, so that four boundary conditions are needed. At each end, two boundary conditions are required, one condition involves torsion, and the other one involves warping. 


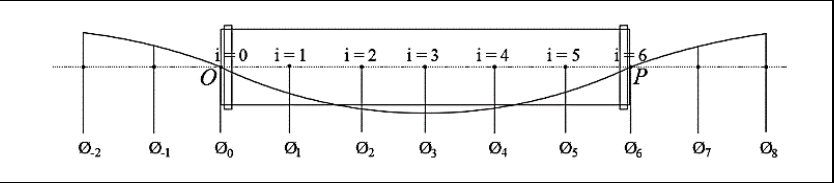

Figure 2: Example of grid points in finite difference approximation.

Finite difference representation of differential equation at any arbitrary point $i$. becomes as Eqn. 8 if we use three constants determined with Eqn. 7.

$$
\begin{gathered}
a=\frac{E C_{w}}{\Delta z^{4}} \quad b=-\frac{G J}{\Delta z^{2}} \quad c=-\frac{M_{0}^{2}}{E I_{y}} \\
a\left(\emptyset_{i-2}-4 \emptyset_{i-1}+6 \emptyset_{i}-4 \emptyset_{i+1}+\emptyset_{i+2}\right) \\
+b\left(\emptyset_{i-1}-2 \emptyset_{i}+\emptyset_{i+1}\right)+c \emptyset_{i=0}
\end{gathered}
$$

If we assume the beam is divided into, for instance, ten segments. Eq. (8) is then evaluated at grid points $i=0,1,2, \ldots, 10$ so there are eleven equations. The boundary conditions at the two ends are given with Eqn. 9 and Eqn. 10.

$$
\begin{gathered}
\emptyset=\left.0\right|_{z=0, z=L} \\
\frac{d^{2} \emptyset}{d z^{2}}=\left.0\right|_{z=0, z=L}
\end{gathered}
$$

In the finite difference approach, Eqn. 9 and Eqn. 10 can be written in the form as in Eqn. 11 and the beam is divided into $m$ segments.

$$
\begin{array}{c|c}
\emptyset_{i}=0 \\
\emptyset_{i-1}-2 \emptyset_{i}+\emptyset_{i+1}=0 & \begin{array}{l}
z=0 \rightarrow i=0 \\
z=L \rightarrow i=m
\end{array}
\end{array}
$$

Eleven finite difference representation at the grid points and two additional boundary conditions at each end make a linear simultaneous equation system of the size of fifteen.

In this study, a member subjected to unequal end moments as in Figure 3 is focused and finite difference approach is applied using Matlab [29]. Afterwards, a function is proposed using the finite difference approach outcomes to be used in lateral torsional buckling calculations practically.

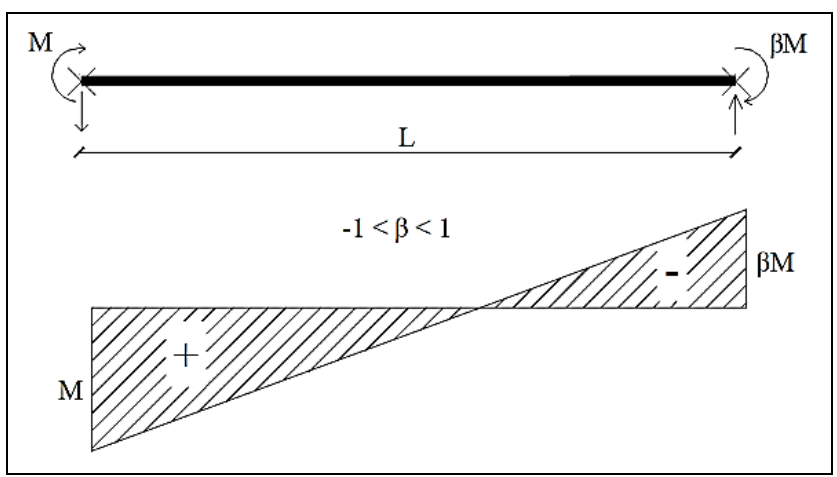

Figure 3: Bending moment diagram in a member subjected to unequal end moments.

In Figure 3, a member with an end moment $M$ at one end and $\beta M$ at the other end is shown. $M$ is chosen the larger absolute end moment so that $\beta$ ranges from -1 to +1 for considering potential different cases of member end moments. The bending moment equation for this case is shown with Eqn. 12.

$$
\mathrm{M}_{0}=\mathrm{M}-(1+\beta) \frac{\mathrm{M}}{\mathrm{L}} \cdot \mathrm{z}
$$

where $\mathrm{z}$ is measured from the beam end where the moment $M$ acts. For finite difference approach, Eqn. 12 can be written as Eqn. 13.

$$
M_{0}=M\left[1-(1+\beta) \frac{i}{L} \cdot \Delta z\right]
$$

where $\mathrm{z}=\mathrm{I} \cdot \mathrm{z}$. By substituting moment $M_{0}$ in Eqn. 13 into Eqn. 1, the differential equation used in the finite difference approach for this load case becomes as Eqn. 14.

$$
E C_{w} \frac{d^{4} \emptyset}{d z^{4}}-G J \frac{d^{2} \emptyset}{d z^{2}}-\frac{M_{0}^{2}}{E I_{y}}\left[1-(1+\beta) \frac{i}{m}\right]^{2} \emptyset=0
$$

Finite difference calculation procedure that is used for the basic case is followed for solving the differential equation in Eqn. 14. An analysis code is written using Matlab [29] and boundary conditions are considered in the calculations. In the analysis, member is divided into 300 elements considering accuracy of analysis results. Critical moment due to lateral torsional buckling is determined and moment modification factor is presented for each moment gradient value. Finite difference analysis results are shown in Table 1.

Table 1: Moment modification factor for the member.

\begin{tabular}{cc}
\hline$\beta$ & $C_{b}$ Finite Difference Method \\
\hline-1.0 & 1.000 \\
-0.9 & 1.052 \\
-0.8 & 1.110 \\
-0.7 & 1.173 \\
-0.6 & 1.242 \\
-0.5 & 1.317 \\
-0.4 & 1.401 \\
-0.3 & 1.492 \\
-0.2 & 1.593 \\
-0.1 & 1.702 \\
0 & 1.820 \\
0.1 & 1.946 \\
0.2 & 2.080 \\
0.3 & 2.219 \\
0.4 & 2.359 \\
0.5 & 2.497 \\
0.6 & 2.625 \\
0.7 & 2.729 \\
0.8 & 2.792 \\
0.9 & 2.786 \\
1.0 & 2.693 \\
\hline
\end{tabular}

A practical function to be used in lateral torsional buckling calculations is proposed considering the $\beta$ values and moment modification factors. This function is presented with Eqn. 15. Also, regression equation is calculated as $R^{2}=1.00$ for the sixth degree proposed polynomial considering the data computed by using finite difference approach.

$$
\begin{aligned}
C_{b}=-0.1452 \beta^{6}+ & 0.3063 \beta^{5}-0.2576 \beta^{4}+0.0667 \beta^{3} \\
& +0.4294 \beta^{2}-1.2239 \beta+1.8294
\end{aligned}
$$

Relationship between moment modification factor and $\beta$ value of the end moments are shown in Figure 4. 


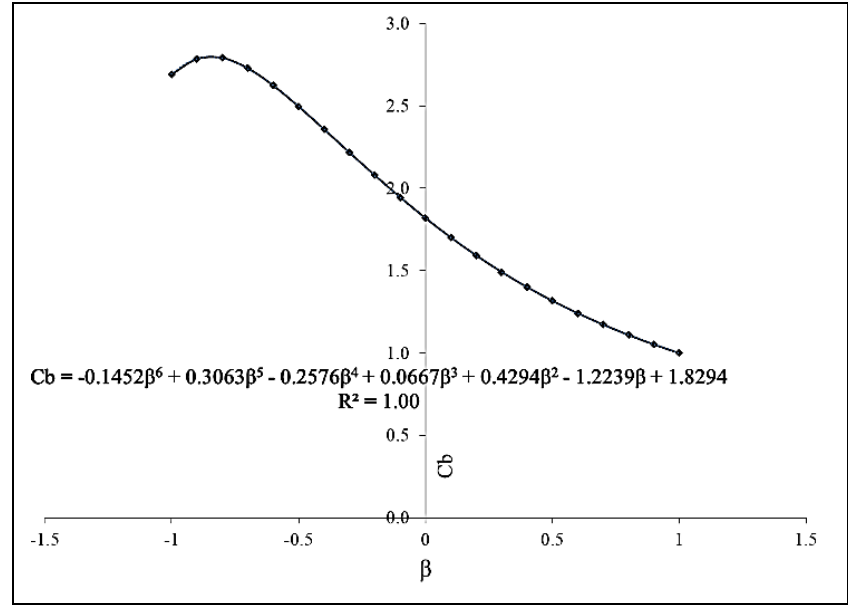

Figure 4: $\mathrm{Cb}$ factors for a beam subjected to unequal end moments.

\subsection{Lateral torsional buckling analysis using design standards and codes}

Internationally accepted standards and codes such as; EN 1993-1-1 [21], BS 5950 [22], AS 4100 [23], AISC 360-16 [24], TSDC-2016 [25] and TS 4561 [26] are presented for lateral torsional buckling equations.

\subsubsection{EN 1993-1-1}

Critical elastic lateral torsional buckling moment capacity for the case of beams with doubly symmetric sections and simply supported ends and subjected to a constant moment over the laterally unbraced length is given with Eqn. 16 in EN 1993-1-1 [21]. In this Eurocode equation, member is assumed to be loaded from shear center.

$$
M_{c r}=C_{1} \frac{\pi^{2} E I_{z}}{(k L)^{2}}\left[\left(\frac{k}{k_{w}}\right)^{2} \frac{I_{w}}{I_{z}}+\frac{(k L)^{2} G I_{t}}{\pi^{2} E I_{z}}\right]^{0.5}
$$

where: $I_{t}$ is the torsion constant, $I_{w}$ is the warping constant, $I_{z}$ is the second moment of area about the minor axis and $L$ is the length of the beam between points which have lateral restraint, $E$ is the modulus of the elastic. The effective length factors $\mathrm{k}$ and $k_{w}$ vary from 0.5 for full fixity to 1.0 for no fixity, with 0.7 for one end fixed and one end free. For a case with $k$ is equal to 1.0, the value of $C_{1}$ for any ratio of end moment loading is given with Eqn. 17 [21].

$$
C_{1}=1.88-1.4 \Psi+0.52 \Psi^{2} \leq 2.70, \Psi=\frac{M_{S}}{M_{L}}
$$

where: $\Psi$ is the ratio of end moment loading.

\subsubsection{BS 5950}

British code for steelworks in buildings [22] presents a formulation in order to determine elastic moment capacity under lateral torsional buckling. BS 5950 provides an equivalent uniform moment factor with $C_{1}$ as in Eqn. 18.

$$
C_{1}=\frac{M_{\max }}{0.2 M_{\max }+0.15 M_{A}+0.5 M_{B}+0.15 M_{C}} \leq 2.273
$$

Where: values of $M_{\max }$ is the absolute maximum moment along $L_{b}, M_{A}, M_{B}$ and $M_{C}$, are the absolute moments at the quarter, center, and three-quarter point, respectively.

\subsubsection{AS 4100}

Australian steel design standard AS 4100 [23] gives nominal member moment capacity under elastic lateral torsional buckling with Eqn. 19.

$$
M_{b}=\alpha_{m} \alpha_{s} M_{s} \leq M_{s}
$$

where: $M_{b}$ is the nominal member moment capacity, $M_{s}$ the nominal section moment capacity, $M_{o a}$ is the reference buckling moment, $\alpha_{m}$ and $\alpha_{s}$ are determined in Eqn. 20 and Eqn. 21, respectively.

$$
\begin{gathered}
\alpha_{m}=\frac{1.7 M_{m}}{\sqrt{\left[M_{2}^{2}+M_{3}^{2}+M_{4}^{2}\right]}} \leq 2.5 \\
\alpha_{s}=0.6\left[\sqrt{\left(\frac{M_{s}}{M_{o a}}\right)^{2}+3}\right]-\left(\frac{M_{s}}{M_{o a}}\right)
\end{gathered}
$$

\subsubsection{AISC 360-10}

AISC 360-10 [24] specification defines the nominal elastic lateral torsional buckling with Eqn. 22.

$$
M_{c r}=C_{b} \frac{\pi}{L_{b}} \sqrt{E I_{z} G I_{t}+\left(\frac{\pi E}{L_{b}}\right)^{2} I_{z} I_{w}}
$$

Where: $L_{b}$ is the lateral buckling length and $C_{b}$ is the moment modification factor.

Moment modification factor is studied in order to improve the capability of representing lateral torsional buckling behavior. Since moment modification factor studies are evaluated in the present study, these factors are summarized considering the relevant literature.

Moment modification factor is first studied by Salvadory (1955) with using Eqn. 23 considering linear moment distribution between the brace points [14].

$$
C_{b}=1.75-1.05 \Psi+0.3 \Psi^{2} \leq 2.3
$$

Kirby and Nethercot (1979) presented an alternative equation for $C_{b}$, which is applicable for any shape of moment diagrams [26]. A slightly modified version is given in Eqn. 24 and is adopted by AISC 360-10 for any moment distribution [16].

$$
C_{b}=\frac{12.5 M_{\max }}{2.5 M_{\max }+3 M_{A}+4 M_{B}+3 M_{C}}
$$

Wong and Driver (2008), proposed an equation for $C_{b}$ factor and it is presented in Eqn. 25 [18].

$$
C_{b}=\frac{4 M_{\max }}{\sqrt{M_{\max }^{2}+4 M_{A}^{2}+7 M_{B}^{2}+4 M_{C}^{2}}} \leq 2.5
$$

\subsubsection{TSDC-2016}

TSDC-2016 [25] presents an approach for determining the lateral torsional buckling effects for the steel frame members and it is summarized in this part. This approach is same as AISC 360-10 [24] equations, and it classifies elastic and inelastic buckling considering unbraced length limits.

In TSDC-2016, unbraced length exceeds unbraced length limit, elastic lateral torsional buckling may occur and Eqn. 26 and Eqn. 27 are used for calculating $M_{n}$. 


$$
\begin{gathered}
M_{n}=F_{c r} W_{e x} \leq M_{p} \\
F_{c r}=\frac{C_{b} \pi^{2} E}{\left(\frac{L_{b}}{i_{t s}}\right)^{2}} \sqrt{1+0.078 \frac{J c}{W_{e x} h_{o}}\left(\frac{L_{b}}{i_{t s}}\right)^{2}}
\end{gathered}
$$

where: $F_{c r}$ is the critical yielding point, $L_{b}$ is the length of the unbraced segment of the member, $E$ is the modulus elasticity of steel, $W_{e x}$ is the elastic section modulus about strong axis, $J$ is the torsional constant, $h_{o}$ is the distance between the flange centroids.

\subsubsection{TS 4561}

Design standard TS 4561 [26] was used in structural steel design practice in Turkey up to publication of TS EN 1993-1-1 [30]. After the publication of TS EN 1993-1-1 [30] in 2005, TS 4561 [26] standard was abolished. In the present study, TS 4561 [26] is considered for evaluating the development in the design procedure of the elastic buckling moment calculations. Eqn. 28, Eqn. 29 and Eqn. 30 are used to calculate critical buckling moment due to TS 4561 standard [26].

$$
\begin{gathered}
M_{K r}=k_{D} M_{p} \\
k_{D}=\frac{1}{\sqrt[3]{1+1.3\left(\frac{M_{p}}{M_{D}}\right)^{3}}} \\
M_{D} \\
=C_{1} \frac{\pi^{2} E I_{y}\left(h-t_{b}\right)}{2 L_{D} L}\left[\sqrt{1+\left(\eta C_{2}\right)^{2}+\frac{G K_{T}}{E I_{y}}\left(\frac{2 L}{\pi h}\right)^{2}+\eta C_{2}}\right]
\end{gathered}
$$

Where: $M_{K r}$ is the maximum bending moment that the section can bear without lateral torsional buckling and axial load effect, $M_{p}$ is plastic moment, $M_{D}$ is critical elastic moment for lateral torsional buckling, $I_{y}$ is moment of inertia relative to the weak principal axis of the section, $L$ is lateral unbraced length of the beam, $G K_{T}$ is section torsional stiffness, $t_{b}$ is section flange thickness, $h$ is section height, $\eta$ is the ratio of the distance between the load impact point and the centre of gravity to the half-height of the section, $C_{m}$ is a constant provided in the standard.

\subsection{Lateral torsional buckling using finite element analysis}

Beside the standard and codes, finite element based programs can be used to determine the critical moment for members under lateral torsional buckling. Finite element based software has high capacities and can consider both geometric and material nonlinearities in the analyses steps [31]. However, structural modelling and analysis steps are time-consuming and require over-qualified engineers.

In Figure 5, lateral torsional buckling of I-shaped members are illustrated by using ANSYS [31]. When I-shaped members are loaded in its major principle plane, upper flange goes into compression, which means it is trying to get shorter. This flange will therefore tend to buckle out sideways.

In the study, four side shell elements SHELL 43 from the ANSYS element library are used to model the web and both flanges. Buckling analyses are performed with mesh sizes about 40 x 40 mm using finite element model. Mesh arrangement used in the analysis is also shown in Figure 5.

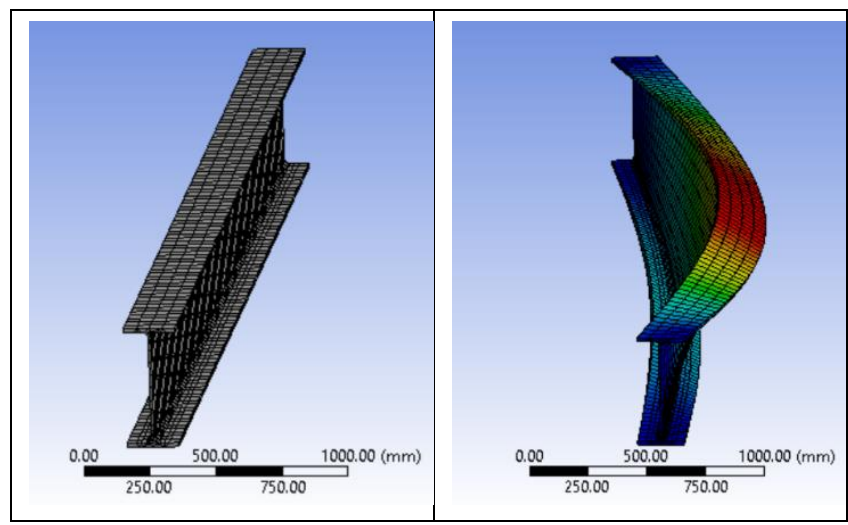

Figure 5: Lateral torsional buckling with FE analysis [31].

\section{Numerical examples}

Lateral torsional buckling behaviors of I-shaped steel member are examined considering a simply supported steel beam having IPE 500 section as shown in Figure 6. This beam is subjected to linear moment gradient and section is given in Figure 7.

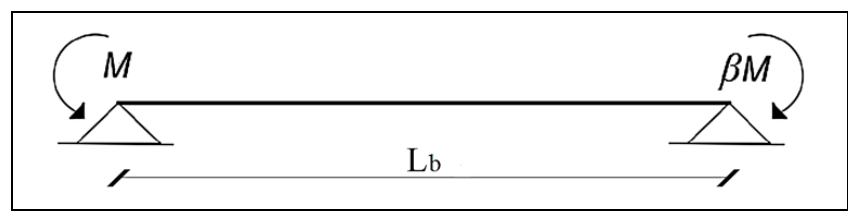

Figure 6: Simply supported I-shaped member under linear moment gradient.

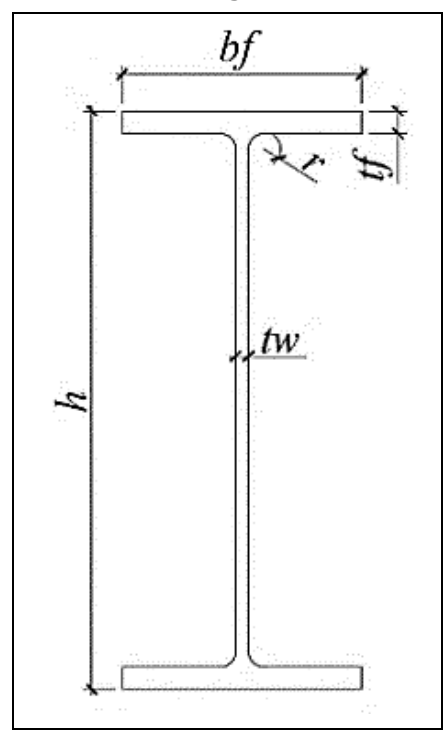

Figure 7: I-shaped steel member section.

Section properties for IPE 500 section is defined considering Figure 7. Height of the section, $h$ is $500 \mathrm{~mm}$, width of the flange, $b_{f}$ is $200 \mathrm{~mm}$, radius of the section, $r$ is $21 \mathrm{~mm}$, thickness of the flange, $t_{f}$ is $16 \mathrm{~mm}$, thickness of the web, $t_{w}$ is $10.2 \mathrm{~mm}$, torsion constant, $I_{t}$ is $89.3 \times 10^{4} \mathrm{~mm}^{4}$, warping constant, $I_{w}$ is $1249 \times 10^{9}$ $\mathrm{mm}^{6}$, second moment of area about the minor axis, $I_{z}$ is $2142 \mathrm{x}$ $10^{4} \mathrm{~mm}^{4}$. Modulus of Elasticity and Poisson ratio are selected as $200 \mathrm{GPa}$ and 0.3 , respectively. 
In the first step, proposed formula based on finite difference analysis is used for calculation of the moment modification factor due to moment gradient. Afterwards, outcomes of the proposed formula is evaluated considering several standards, codes such as; EN 1993-1-1 [21], BS 5950 [22], AS 4100 [23], AISC 360-10 [24], TSDC-2016 [25], TS 4561 [26] and recommended moment modification factor equations by the researchers from the literature $[14,16,18]$. Finally, finite element based ANSYS [31] is used to validate the proposed formula.

In order to investigate the structural behavior and the efficiency of the proposed formula, various end moment ratios $-1<\beta<1$, different unbraced length conditions are considered in the present study. These unbraced lengths $L_{b}$, are selected as $8 \mathrm{~m}, 10 \mathrm{~m}, 12 \mathrm{~m}$, and $16 \mathrm{~m}$ to represent realistic members.

Unbraced member length of $8 \mathrm{~m}$ is first used for determining elastic lateral torsional buckling moment capacity considering the changes in the moment ratio values. Outcomes of the analyses are given in Figure 8 and Figure 9.

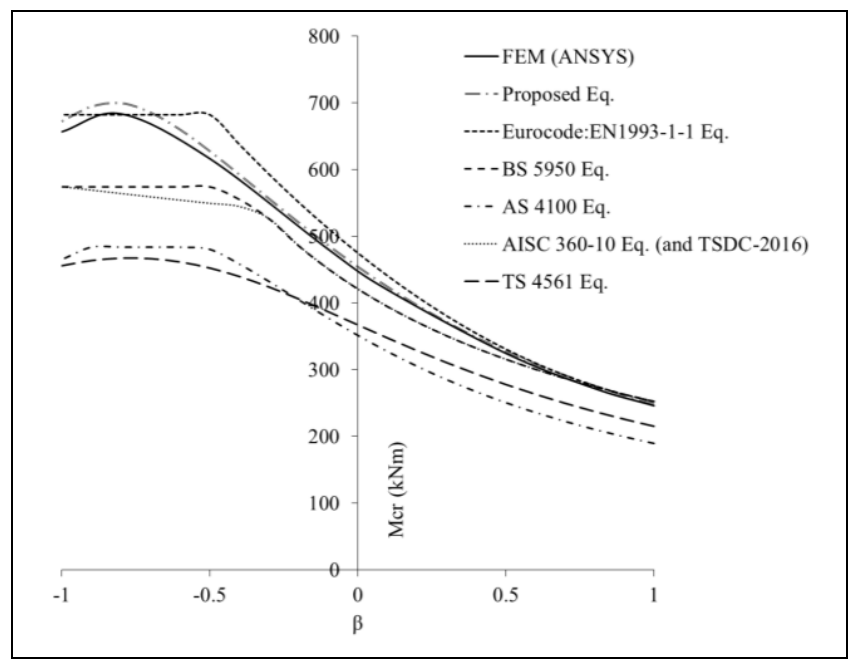

Figure 8: End moment ratio $(\beta)$ and $M_{c r}$ for doubly symmetric I-beam with $L_{b}=8 \mathrm{~m}$.

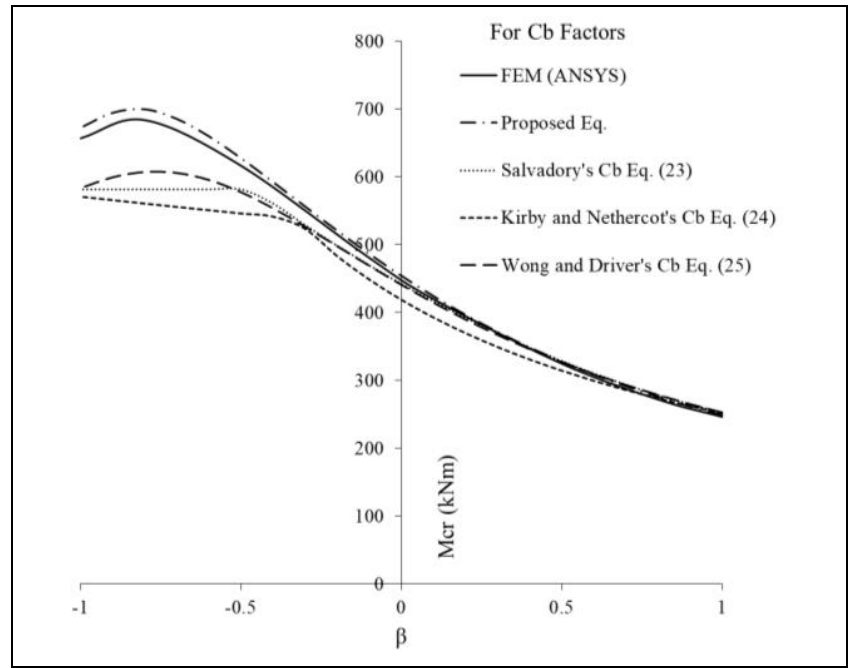

Figure 9: End moment ratio $(\beta)$ and $M_{c r}$ for doubly symmetric I-beam with $L_{b}=8 \mathrm{~m}$ considering $\mathrm{C}_{\mathrm{b}}$ factors.

Unbraced member length of $10 \mathrm{~m}$ is analyzed and results are presented in Figure 10 and Figure 11.

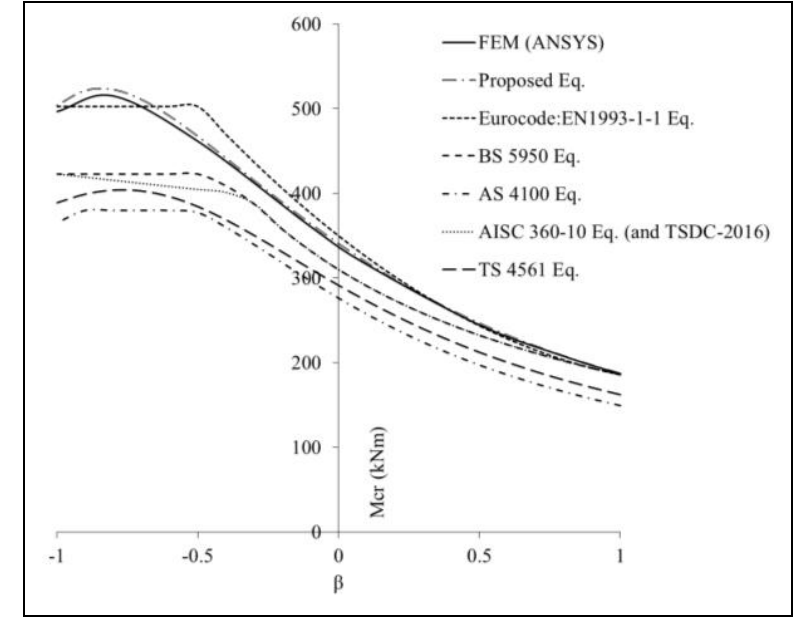

Figure 10: End moment ratio $(\beta)$ and $M_{c r}$ for doubly symmetric I-beam with $L_{b}=10 \mathrm{~m}$.

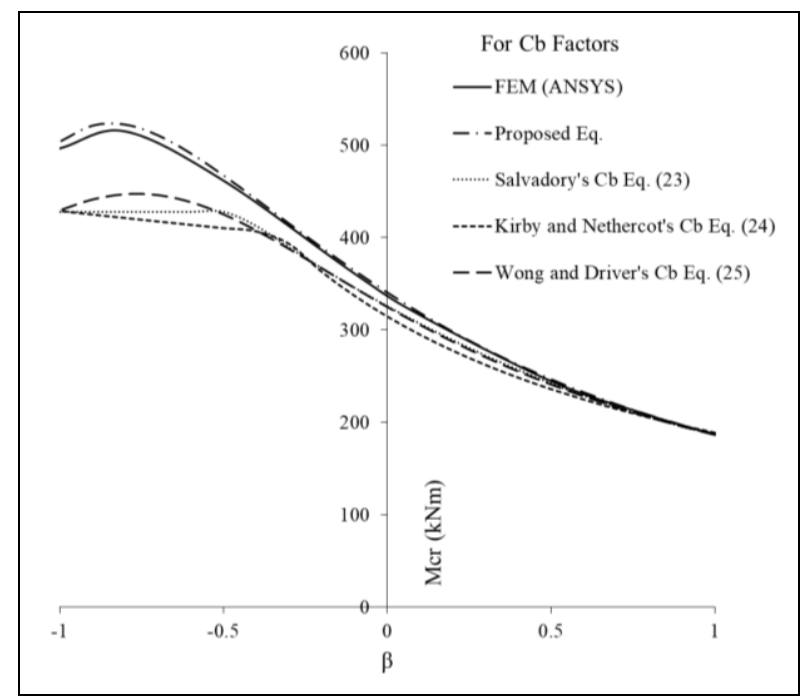

Figure 11: End moment ratio $(\beta)$ and $M_{c r}$ for doubly symmetric I-beam with $L_{b}=10 \mathrm{~m}$ considering $C_{b}$ factors.

Unbraced member length of $12 \mathrm{~m}$ is analyzed and results are presented in Figure 12 and Figure 13.

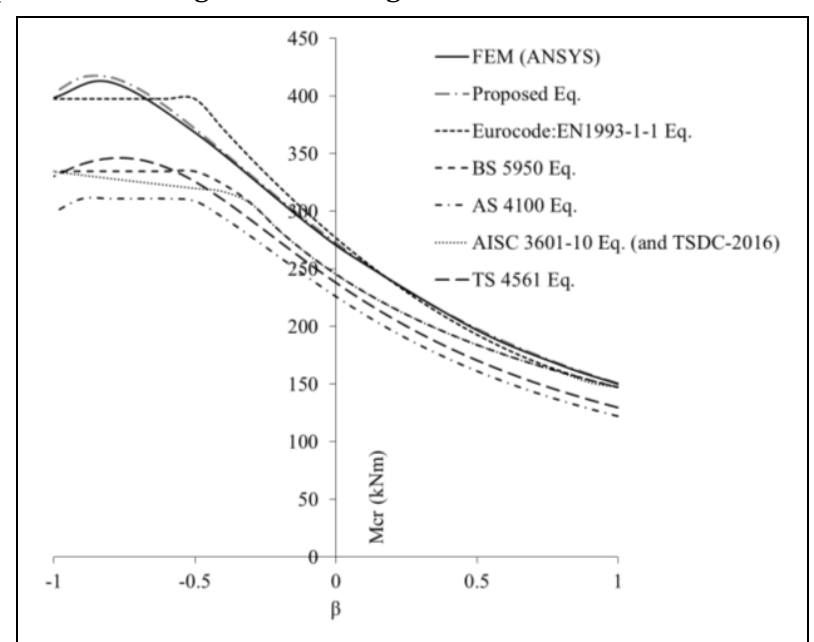

Figure 12: End moment ratio $(\beta)$ and $M_{c r}$ for doubly symmetric I-beam with $\mathrm{Lb}=12 \mathrm{~m}$. 


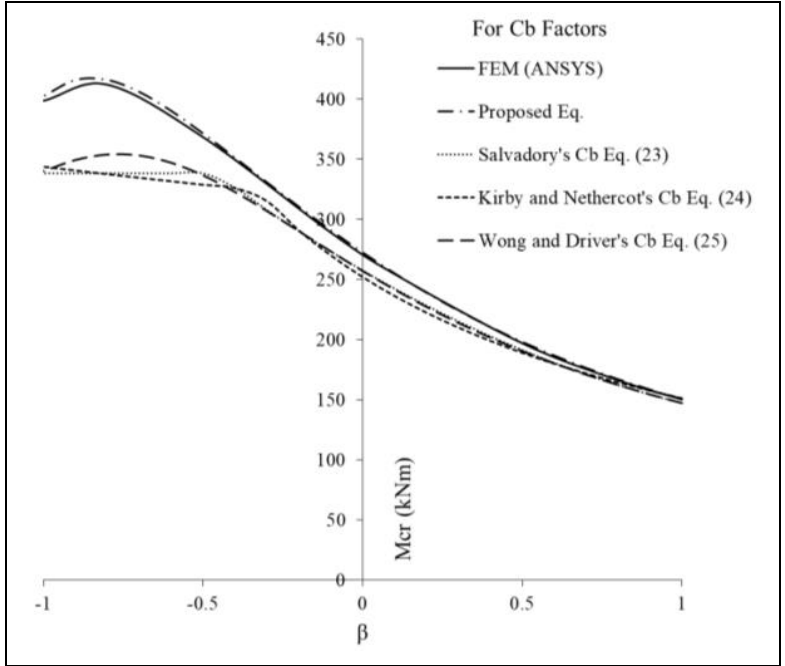

Figure 13: End moment ratio $(\beta)$ and $M_{c r}$ for doubly symmetric I-beam with $\mathrm{L}_{\mathrm{b}}=12 \mathrm{~m}$ considering $C_{b}$ factors.

Finally, unbraced member length of $16 \mathrm{~m}$ is analyzed and results are presented in Figure 14 and Figure 15.

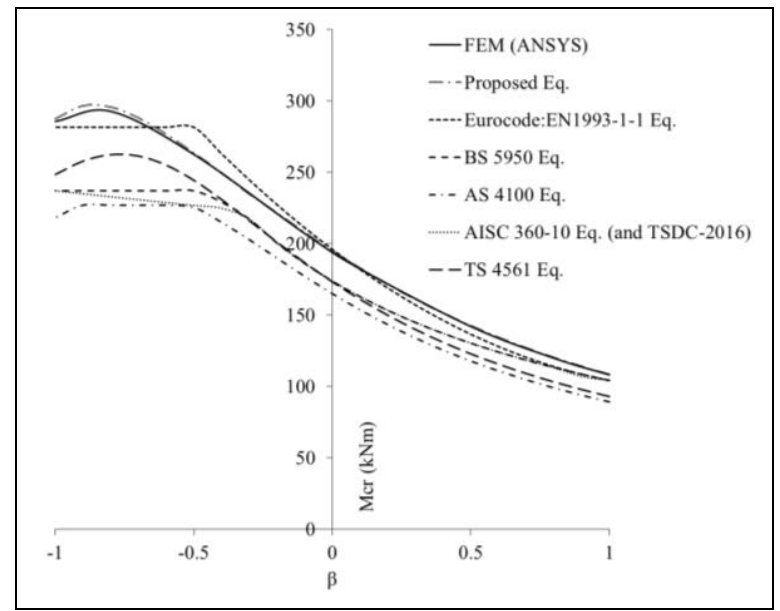

Figure 14: End moment ratio $(\beta)$ and $M_{c r}$ for doubly symmetric I-beam with $\mathrm{L}_{b}=16 \mathrm{~m}$.

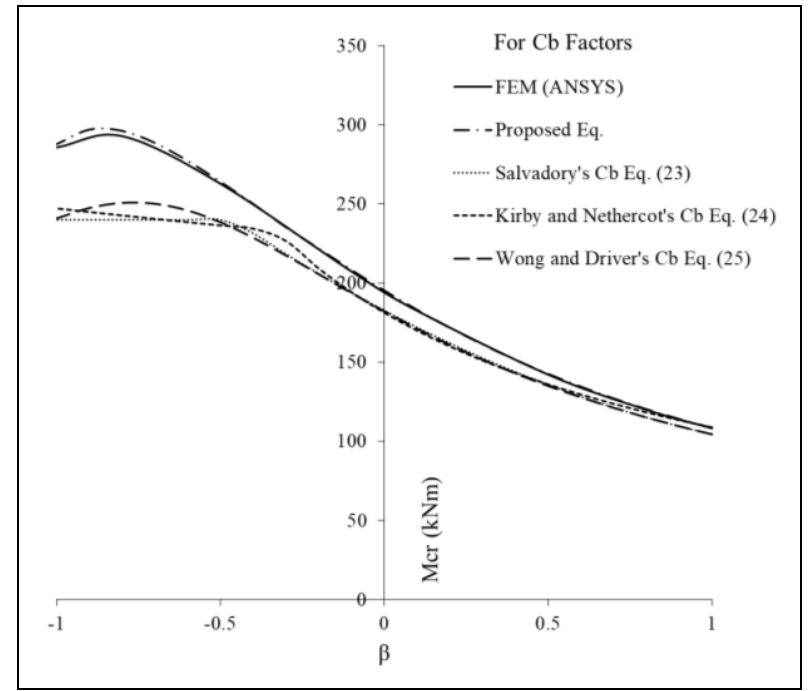

Figure 15: End moment ratio $(\beta)$ and $M_{c r}$ for doubly symmetric I-beam with $\mathrm{Lb}_{\mathrm{b}}=16 \mathrm{~m}$ considering $C_{b}$ factor.

\section{Conclusions}

Lateral torsional buckling behavior of I-shaped steel members is investigated and a function based on finite difference approach is proposed for practical calculations. Proposed function is evaluated considering several design standard and code approaches, methods from literature and finite element program outcomes using different unbraced member lengths and linear moment gradient. Relationships between end moment ratio and critical moment are plotted and analysis results for moment modification factors are presented. The outcomes from the study are presented below.

1) Lateral torsional buckling is a key issue for I-shaped steel members that are under linear moment gradient and it is reflected satisfactorily with the proposed function considering finite element analysis results, methods from literature and design codes and standards,

2) According to the numerical example of the study; critical moment values for TS 4561 and AS 4100 are slightly low when compared other specification results. Therefore, they give more conservative results than the other approaches. BS 5950 give close results with AISC 360-10 and TSDC-2016 results. Results of EN 1993-1-1 are generally close to FEM and proposed equation results,

3) Unbraced member length increases because significant decrease in elastic moment capacity under lateral torsional buckling as it can be realized from the graphics. For instance, considering $\beta=0$ end moment ratio, decrease in critical moment capacity for $L_{b}=10$ $\mathrm{m}, \mathrm{Lb}=12 \mathrm{~m}$ and $\mathrm{Lb}=16 \mathrm{~m}$ due to $\mathrm{Lb}=8 \mathrm{~m}$ is $26.4 \%$, $41.7 \%$ and $58.8 \%$ respectively. Therefore, differences in between analysis approaches results decrease with the increase of the unbraced member length,

4) In order to improve the accuracy of determining the critical moment capacity, moment modification factors from the literature are also investigated in the study. Numerical examples of this study show that; proposed $\mathrm{C}_{\mathrm{b}}$ equation give more close results to finite element analysis outcomes than any other approaches considered in the study,

5) Proposed equation is derived for determining lateral torsional buckling behavior under linear moment gradient and therefore it is specific for the case. However, lateral torsional buckling equations in design standards and codes cover several load cases for structural members and therefore they are more general and useful.

\section{References}

[1] Xiong G, Kang SB, Yang B, Wang S, Bai J, Nie S, Dai G. "Experimental and numerical studies on lateral torsional buckling of welded Q460GJ structural steel beams". Engineering Structures, 126, 1-14, 2016.

[2] Taras A, Greiner R. "New design curves for lateral-torsional buckling-Proposal based on a consistent derivation". Journal of Constructional Steel Research, 66(5), 648-663, 2010.

[3] Uzun ET. Nonlinear Analysis of Steel Frames Considering Lateral Torsional Buckling. MSc Thesis, Izmir Katip Celebi University, Izmir, Turkey, 2017. 
[4] Valarinho L, Correia JR, Costa MM, Branco FA, Silvestre N. "Lateral-torsional buckling behaviour of long-span laminated glass beams: Analytical, experimental and numerical study". Materials and Design, 102, 264-275, 2016.

[5] Dou C, Pi YL. "Flexural-torsional buckling resistance design of circular arches with elastic end restraints". Journal of Structural Engineering, 142(2), 04015104-104015104-10, 2015.

[6] Taras A, Greiner R. "Torsional and flexural torsional buckling-A study on laterally restrained I sections". Journal of Structural Steel Research, 64(7), 725-731, 2008.

[7] Agüero A, Pallarés FJ, Pallarés L. "Equivalent geometric imperfection definition in steel structures sensitive the lateral torsional buckling due to bending moment". Engineering Structures, 96, 41-55, 2015.

[8] Bradford MA, Pi YL. "A new analytical solution for lateral torsional buckling of arches under axial uniform compression". Engineering Structures, 41, 14-23, 2012.

[9] Wu L, Mohareb M. "Finite-element formulation for the lateral torsional buckling of plane frames". Journal of Engineering Mechanics, 139(4), 512-524, 2013.

[10] Zhang X, Rasmussen KJR, Zhang H. "Experimental investigation of locally and distortionally buckled portal frames". Journal of Constructional Steel Research, 122, 571-583, 2016.

[11] Wang Y, Yang L, Gao B, Shi Y, Yuan H. "Experimental study of lateral-torsional buckling behavior of stainless steel welded I-section beams". International Journal of Steel Structures, 14(2), 411-420, 2014.

[12] Lim NH, Park NH, Kank YJ, Sung IH. "Elastic buckling of Ibeams under linear moment gradient". Solids and Structures, 40, 5635-5647, 2003.

[13] White DW, Kim YD. “Unified flexural resistance equations for stability design of steel I-section members: Moment gradient tests". Journal of Structural Engineering, 134, 1471-1486, 2008.

[14] Salvadory MG. "Lateral buckling of I-beams". ASCE Transaction, 120, 1165-1177, 1955.

[15] Moon J, Lim NH, Lee HE. "Moment gradient correction factor and inelastic flexural-torsional buckling of I-girder with corrugated steel webs". Thin-Walled Structures, $62,18-27,2013$.
[16] Kirby PA, Nethercot DA. Design for Structural Stability. $1^{\text {st }}$ ed. New York, USA, Halsted Press, 1979.

[17] Serna MA, Lopez A, Puente I, Yong DJ. “Equivalent uniform moment factors for lateral-torsional buckling of steel members." Journal of Constructional Steel Research, 62, 566-580, 2005.

[18] Wong E, Driver RG. "Critical evaluation of equivalent moment factor procedures for laterally unsupported beams." AISC Engineering Journal, 47, 1-20, 2010.

[19] Galambos TV, Surovek AE. Structural Stability of Steel: Concepts and Applications for Structural Engineers. $1^{\text {st }}$ ed. USA, Wiley, 2008.

[20] Ziemian RD. Guide to Stability Design Criteria for Metal Structures. $6^{\text {th }}$ ed. USA, Wiley, 2010.

[21] European Committee for Standardization. "Design of steel structures-Part 1-1: General Rules and Rules for Buildings, EN1993-1-1". Brussel, Belgium, 1992.

[22] British Standards Institution. "Structural use of steelwork in building, BS5950-1". London, UK, 2000.

[23] Standards Association of Australia. "Steel structures. Standards Australia, AS4100". Sydney, Australia, 1998.

[24] American Institute of Steel Construction. "Specification for Structural Steel Buildings, ANSI/AISC360-10". Chicago-Illinois, USA, 2010.

[25] Ministry of Environment and Urbanization. "Turkish Steel Design Code, TSDC". Ankara, Turkey, 2016.

[26] Turkish Standard Institution. "Calculation Rules According to Plastic Theory of Steel Structures, TS4561". Ankara, Turkey, 1985.

[27] Secer M, Uzun E.T. "Nonlinear analysis of steel frames accounting lateral torsional buckling". 21st International Scientific Conference: Mechanika 2016, Lithuania, 12-13 May 2016.

[28] Timoshenko SP, Gere JM. Theory of Elastic Stability. $2^{\text {nd }}$ ed. Tokyo, McGraw Hill-Kogakusha Ltd, 1961.

[29] MATLAB Version R2013a, The MathWorks Inc., Natick, MA, USA, 2013

[30] Turkish Standard Institution. "Eurocode 3: Design of steel structures-Part 1-1: General Rules and Rules for Buildings TS EN 1993-1-1". Ankara, Turkey, 2005.

[31] ANSYS H. Version 15.0, Ansys. Inc., Canonsburg, PA USA, 2013. 